\title{
Notes on the genus Pterygosquilla Hilgendorf, 1890 (Stomatopoda: Squillidae) in Chile
}

\author{
Michel E. Hendrickx ${ }^{1 *}$ and Marco Retamal Rivas ${ }^{2}$
}

\begin{abstract}
Background: Pterygosquilla is a large-size genus of the stomatopod family Squillidae. It contains four species of which two, P. armata (Milne Edwards H, Histoire naturelle des crustacés, comprenant l'anatomie, la physiologie et la classification de ces animaux 2, 1837) and P. gracilipes Miers, 1881, have been recorded in the Americas. Three subspecies of $P$. armata (P. armata armata, P. armata gracilipes, and P. armata capensis Manning, 1969 were recognised by Manning (Stomatopod Crustacea of the western Atlantic, 1969) but Ahyong (The Marine Fauna of New Zealand: Mantis shrimps (Crustacea: Stomatopoda); 125: 1-111, 2012) showed they should be separate species.

Methods: New material of Pterygosquilla armata was collected off the coast of Chile, in the eastern Pacific and was compared with previous descriptions available in the literature for P. armata, to the type material of Squilla gracilipes and to additional museum specimens of this species. Special attention was given to the lateral processes of the abdominal somites in both species.

Results: Four males and one female of P. armata collected off Quellón, Punta Lapa, Chile, were studied. They share several diagnostic characters with typical P. armata and also feature a previously unknown character: a remarkable, wing-like, thin lateral extension of abdominal pleura representing up to $50 \%$ of the specimens total width. These extensions had been previously reported for the other American species, P. gracilipes, by Parisi (Elenco degli stomatopodi del Museo di Milano; 61:91-114, 1922). The type material of Squilla gracilipes, held at the Natural History Museum in London, however, lacks these lateral extentions, probably because it is a much smaller specimen.
\end{abstract}

Conclusions: The material reported from off Chile represents a wing-like form of $P$. armata in which the lateral processes of the abdominal pleura are strongly expanded.

Keywords: Stomatopods, Chile, Pterygosquilla

\section{Background}

The genus Pterygosquilla Hilgendorf, 1890 contains four nominal species (Ahyong 2012) and is represented in America by two species, both distributed in the southern cold-temperate water of the continent (Manning, 1969a). Pterygosquilla armata (H. Milne Edwards, 1837) is known from $44^{\circ} \mathrm{S}$ in Argentina (Atlantic Ocean) to Chile, while $P$. gracilipes (Miers, 1881) has so far been reported only off the coast of Chile (Manning 1969b). Both species were

\footnotetext{
* Correspondence: michel@ola.icmyl.unam.mx

'Unidad Académica Mazatlán, Instituto de Ciencias del mar y Limnología, Universidad Nacional Autónoma de México, P.O. Box 811, Mazatlán, Sinaloa 82000, Mexico

Full list of author information is available at the end of the article
}

originally described within the genus Squilla Fabricius, 1787, and later transferred to Pterygosquilla Hilgendorf, 1890 (see Manning 1966, 1969, and Ahyong 2012 for further details related to recognition of Pterygosquilla).

Pterygosquilla armata was described for Argentina, south of $44^{\circ} \mathrm{S}$, without illustrations, and was later reported from the eastern Pacific (coast of Chile as far north as Valparaiso) (see Manning 1969a). Pterygosquilla gracilipes was described on the basis of a young male specimen collected "... from the west coast of Patagonia ..." (sic). A short description was provided together with an illustration of the telson and the last abdominal somite (Miers 1881: 75, plate VII, 8). 
A specimen collected from an unknown locality was reported by Hilgendorf (1890) as Pterygosquilla laticauda Hilgendorf, 1890, and recognized later (Hansen 1895) as a subjective junior synonym of $S$. gracilipes (see Manning 1969a: 123). Hilgendorf was also responsible for the description of Pterygosquilla, of which P. laticauda is the type-species, and in which he included $S$. gracilipes. Subsequent material of $P$. gracilipes was recorded in 1922, when Bruno Parisi reported on five large males (TL 80 to $144 \mathrm{~mm}$ ) in the collection of the Milano Museum, Italia, collected off Valparaiso, Chile (Parisi 1922).

In his report on stomatopods of the west coast of America, Schmitt (1940: 150, 151) included both species of Pterygosquilla (within the genus Squilla, thus ignoring Hilgendorf assignation to Pterygosquilla), but did not report on additional material. Schmitt (loc. cit.) did not refer to any other records of $P$. gracilipes after Parisi's note published in 1922. Bahamonde (1968) noted the presence of $P$. armata armata and $P$. gracilipes along the coast of Chile, provided distinctive features with $P$. armata for the latter, but did not report on new material examined either. Later, Manning (1971) proposed an identification key to species of Stomatopoda of the eastern Pacific, including a couplet for both species of Pterygosquilla.

New material belonging to Pterygosquilla was recently collected in southern Chile and is treated in this contribution.

\section{Results and discussion}

Order STOMATOPODA Latreille, 1817

Family SQUILLIDAE Latreille, 1802

Genus Pterygosquilla Hilgendorf, 1860

Pterygosquilla armata (H. Milne Edwards, 1837)

(Figs. 1, 2, 3)
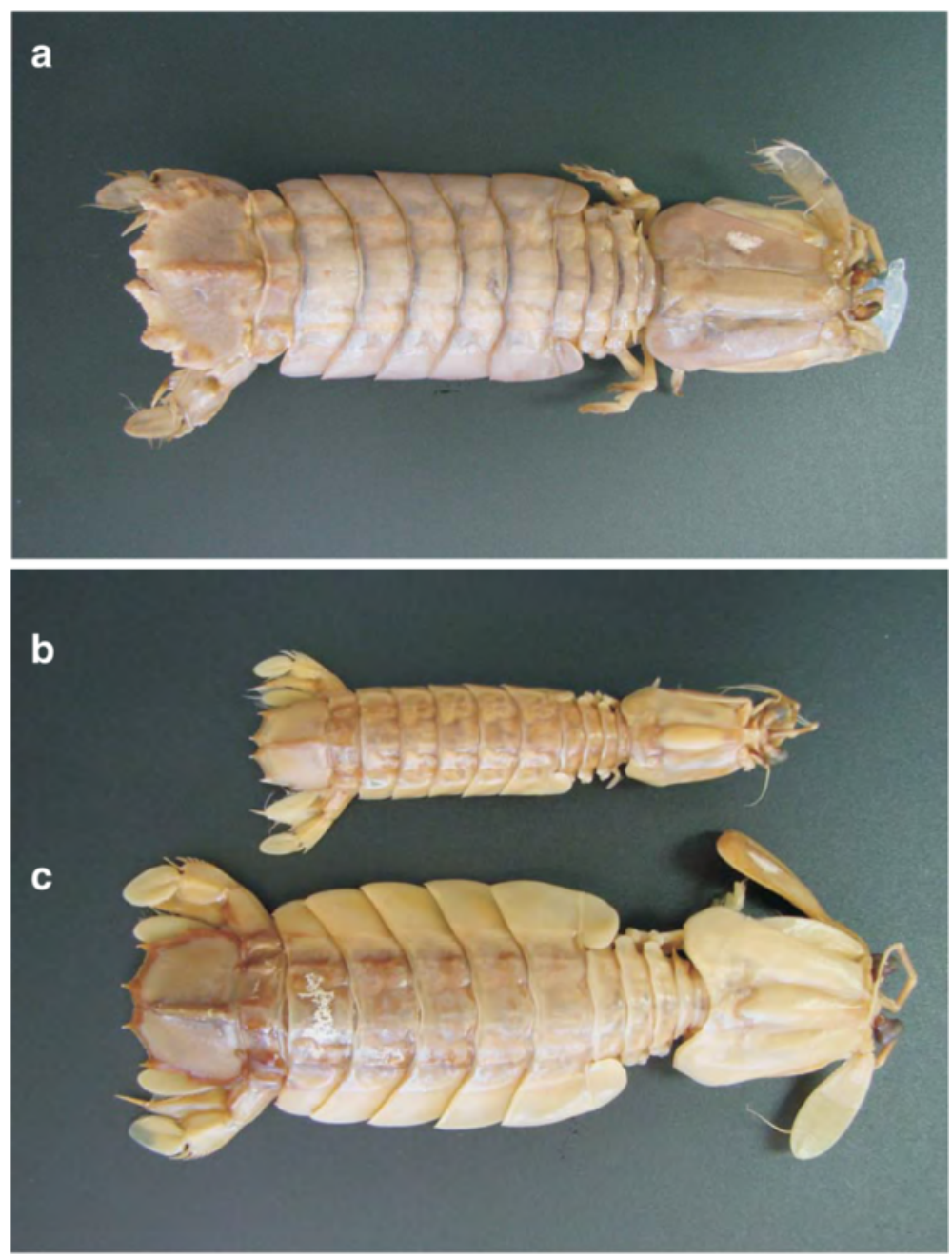

Fig. 1 a Pterygosquilla armata (H. Milne Edwards, 1837), male (148 mm TL), dorsal view (ICML-EMU-7578). b-c Pterygosquilla gracilipes (Miers, 1881), male (80.5 $\mathrm{mm} \mathrm{TL}) \mathbf{b}$ and male (121.0 $\mathrm{mm} \mathrm{TL}) \mathbf{c}$, dorsal view (MCSNM 2324). Scale in $\mathrm{mm}$ 
a

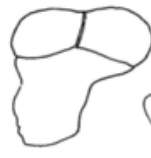

b

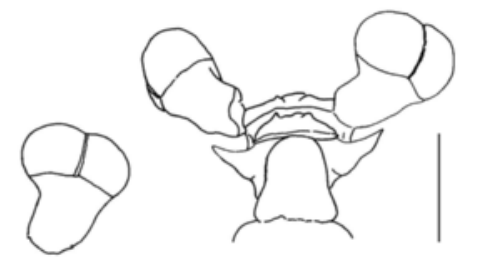

C

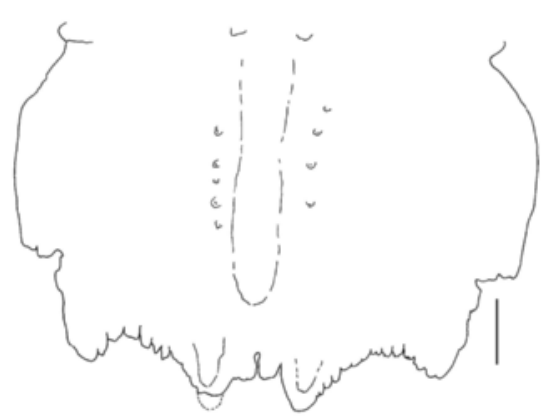

d

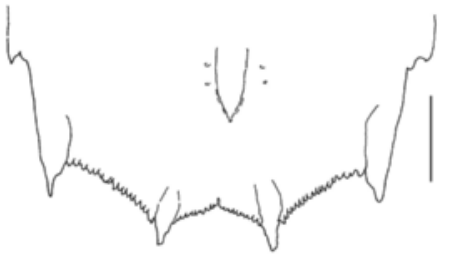

Fig. 2 Pterygosquilla armata (H. Milne Edwards, 1837), male (148 mm TL) (ICML-EMU-7578) (a, c) and Pterygosquilla gracilipes (Miers, 1881), male (80.5 mm TL) (MCSNM 2324) (b, d). a, b Anterior region of carapace and eye (magnified) in dorsal view. c, d Dorsal view of posterior half of telson
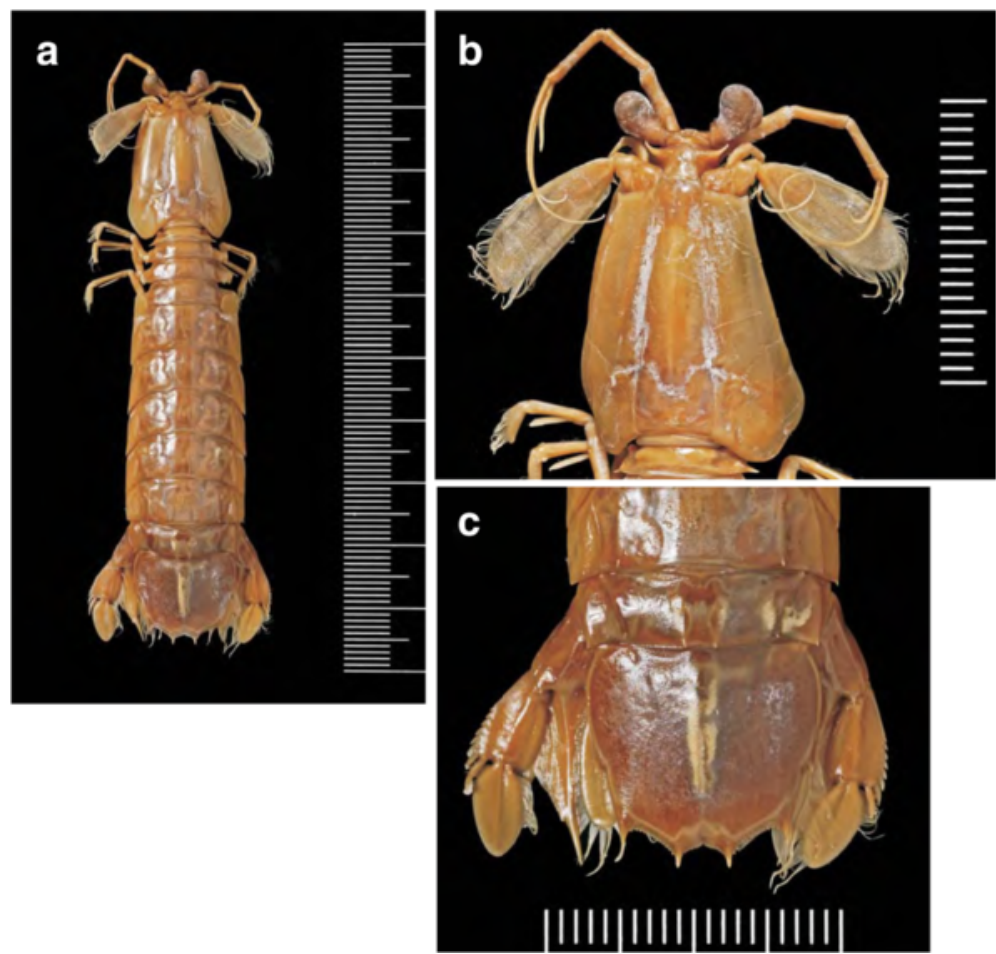

Fig. 3 Squilla gracilipes Miers, 1881. Holotype male (NHM 80.30). a. Dorsal view of body. b. Dorsal view of carapace. c. Dorsal view of telson. Scale in $\mathrm{mm}$ 


\section{Restricted synonymy}

Squilla armata H. Milne Edwards, 1837: 521; Bigelow, 1891: 94; 1894: 515, figures 9-10; A. Milne-Edwards, 1891: 53, plate 7; Parisi, 1922: 93; Schmitt, 1940: 150, figure 4; Manning, 1968: 123 (as a species included in Pterygosquilla).

Pterygosquilla armata.- Manning, 1969a: 123, figure 36; Bahamonde, 1968: 114, figure 5; Ahyong, 2012: 93 (key), 98-99 (passim).

Pterygosquilla armata armata.- Manning, 1971, 101 (key).

\section{Material examined}

Three males (TL 129-135 mm) and one female (TL $110 \mathrm{~mm}$ ), off Quellón, Punta Lapa (430.'22"S; $73^{\circ}$ 3629 'W), Chile, $15 / \mathrm{July} / 2005,50 \mathrm{~m}$, bottom trawl (coll. Marco Retamal) (MZUC 33510); one male (TL $165 \mathrm{~mm}$ ), same date and locality (EMU-7578) (Fig. 1a).

\section{Remarks}

The material examined herein shares several diagnostic characters with typical $P$. armata: the abdominal submedian carinae are still visible as lighter marks, although very much more fainted (absent in $P$. gracilipes); the ventral side of the telson features a strong postanal keel (absent in P. gracilipes); strong, sharp spines are present on ocular scales (Fig. 2a) (reduced or obtuse in P. gracilipes; Fig. 2b); 1 (2) submedian denticles are present on the posterior margin of the telson (Fig. 2c) (vs. up to 26 in P. gracilipes; Fig. 2d. In addition, the cornea is less globulose, the eye more asymmetric in dorsal view in $P$. armata than in $P$. gracilipes, and the rostral plate is relatively wider at its base in $P$. armata (Fig. 2).
Specimens examined feature a remarkable lateral expansion of the abdominal pleura (Fig. 1). Manning (1969a, 1969b) noted that adult males of P. armata show secondary sexual characteristics that include inflated (swollen) margins of the telson and of the abdominal pleura between the intermediate and lateral carinae (also see Manning 1969b, Fig. 3c). In the case of our material, however, in addition to inflated margins of telson, the lateral expansions of all abdominal somites represent up to $50 \%$ of the specimens total width and are wing-like, very thin extensions (Fig. 1; Table 1). Initially, these characteristics were quite puzzling and lead us to believe that this new material from Chile might belong to an undescribed species.

We were not able to find a description of wing-like extensions of abdominal somites in $P$. armata. This feature has been reported for $P$. gracilipes (Miers, 1881) by Parisi (1922: 93) for three of the five males from off Valparaiso, Chile, he examined (called "forma larga", or wide form, by Parisi by contrast to "forma estreta o normale", normal or slender form presented by the two other specimens). Examination of a series of photographs of the holotype of Squilla gracilipes, held in very good condition at the Natural History Museum in London (NHM 80.30) (Fig. 3) (a male of TL ca $89 \mathrm{~mm}$ ), allowed us to conclude that the wing-like lateral extension was not a feature of the type material. Two of the five specimens of $P$. gracilipes originally reported by Parisi (1922), still available at the Milano Museum (MCSNM 2324), were examined in August 2006 (Fig. 1). One of these two obviously belongs to the "forma larga", or wide form, reported by Parisi (1922: 93, Fig. 1) and features remarkable wing-like expansion of the abdominal somites (see Fig. 1c). The jar containing Parisi's material contains a note by the later Raymond Manning,

Table 1 Measurements of specimens of Pterygosquilla armata armata (H. Milne Edwards, 1837) collected off southern Chile during this study and of $P$. gracilipes (Miers, 1881) type and material kept in the Milano Museum

\begin{tabular}{|c|c|c|c|c|c|c|c|}
\hline Spec. & Ref. & Sex & $\mathrm{TL}$ & $\mathrm{CL}$ & Telson W - L (W/L) & $\begin{array}{l}\text { Abd. width (somite 2) } \\
\text { Total-IC (ratio) }\end{array}$ & Teeth on dactylus L/R \\
\hline \multicolumn{8}{|c|}{ Pterygosquilla armata armata } \\
\hline 1 & MZUC 33510 & M & 108 & 21 & 23.8-14.4 (1.65) & $26.3-14.5(1.81)$ & $8 / 8$ \\
\hline 2 & MZUC 33510 & $\mathrm{~F}$ & 117 & 29 & 27.1-16.1 (1.68) & $27.4-16.3(1.68)$ & $8 / 6$ \\
\hline 3 & MZUC 33510 & M & 126 & 35 & $31.6-20.0(1.58)$ & 33.4-21.1 (1.58) & $-/ 8$ \\
\hline 4 & MZUC 33510 & M & 130 & 30 & $31.3-23.3(1.34)$ & $31.5-23.0(1.37)$ & $8 / 8$ \\
\hline 5 & EMU-7578 & M & 148 & 33 & $37.9-29.4(1.29)$ & $45.4-21.8(2.08)$ & $8 / 9$ \\
\hline \multicolumn{8}{|c|}{ Pterygosquilla gracilipes } \\
\hline \multirow[t]{2}{*}{6} & Milano & M & 121 & 25 & $25.5-22.3(1.14)$ & $40.7-16.1(2.53)$ & $10 / 10$ \\
\hline & (Wide form) & & & & & & \\
\hline \multirow[t]{2}{*}{7} & Milano & M & 80.5 & 17 & $14.8-14.6(1.01)$ & $17.4-10.3$ (1.69) & $9 / 9$ \\
\hline & (Slender form) & & & & & & \\
\hline 8 & Type $^{a}$ & M & 89 & 18 & $16.0-15.0(1.10)$ & $17.9-11.1(1.61)$ & $10 / 10^{b}$ \\
\hline
\end{tabular}

All measurements in $\mathrm{mm}$. ${ }^{\mathrm{a}}$ Measured from photographs. ${ }^{\mathrm{b}}$ From Miers (1881). IC, measured between intermediate carinae. L/R, left/right 
indicating that he examined it and identified it as Pterygosquilla gracilipes. A search in Ray Manning's notes at the Smithsonian museum indicates that he only examined two specimens (presumably the same we examined) when he visited the Milano Museum, but we were unable to find any reference to this fact in Manning's contributions.

\section{Conclusions}

For the reasons described above, particularly all the diagnostic characters included in the "Remarks" section, we conclude that the material reported herein from off Chile represents a wing-like form of $P$. armata armata in which the lateral processes of abdominal pleura are strongly expanded in large males, in a way similar to what has been reported for P. gracilipes by Manning (1969a, 1969b) and for P. schizodontia (Richardson, 1953) by Ahyong (2012).

\section{Methods}

During an exploratory cruise along the coast of southern Chile, one of us (MRR) collected a small series of large specimens that proved to belong to the genus Pterygosquilla. This material is reported herein and compared with the previous descriptions and reports of species of this genus, and compared with photographs of the type of $P$. gracilipes deposited in the Natural History Museum, London, Great Britain, and with specimens of this species still available at the Museo Civico di Storia Naturale, Milano, Italy. Ethics, consent and permissions have been followed in the manuscript. The material examined herein was collected within the frame of the Chilean Navy project CIMAR-FIORDOS, with the permission of the "Comite Oceanográfico Nacional", Chili.

\section{Abbreviations}

Abd., abdomen; CL, carapace length; ICML-EMU, Regional Collection of Invertebrates, Mazatlán, Mexico; L, length; MCSNM, Museo Civico di Storia Naturale de Milano; MZUC, Museo de Zoología, Universidad Católica, Chile; NHM, Natural History Museum; TL, total length; W, width.

\begin{abstract}
Acknowledgements
The authors thank Shane T. Ahyong for his useful comments and Mercedes Cordero for final editing of the manuscript. Photographs of the type of $P$. gracilipes were taken at the Museum of Natural History, London, UK. We thank the Museo Civico di Storia Naturale, Milano, Italy, for the loan of specimens of Pterygosquilla armata.
\end{abstract}

\section{Authors' contributions}

MEH elaborated the first draft of the manuscript, reviewed the literature on the subject and examined the material held at the Museo Civico di Storia Naturale, Milano. MRR collected the material, made morphometric observations and measurements, and participate in the final edition of the manuscript. Both authors read and approved the final manuscript.

\section{Authors' information}

MEH is a senior scientist at the Universidad Nacional Autónoma de México, and a specialist in taxonomy and ecology of marine invertebrates. MRR is a senior scientist at the Universidad de Concepción, Facultad de Ciencias Naturales y Oceanográficas, and a specialist in taxonomy and ecology of marine invertebrates.

\section{Competing interests}

The authors declare that they have no competing interests.

\section{Author details}

${ }^{1}$ Unidad Académica Mazatlán, Instituto de Ciencias del mar y Limnología, Universidad Nacional Autónoma de México, P.O. Box 811, Mazatlán, Sinaloa 82000, Mexico. ${ }^{2}$ Facultad de Ciencias Naturales y Oceanográficas. Barrio Universitario S/N Casilla 160-C, Concepción, Universidad de Concepción, Concepción, Chile.

Received: 3 May 2016 Accepted: 6 June 2016

Published online: 22 July 2016

\section{References}

Ahyong ST. The Marine Fauna of New Zealand: Mantis shrimps (Crustacea: Stomatopoda). NIWA Biodiversity Mem. 2012;125:1-111.

Bahamonde N. Bosquejo taxonómico sobre los estomatópodos de Chile (Crustacea, Stomatopoda). Revista Universitaria, Universidad Católica de Chile. 1968:31:107-20.

Bigelow RP. Preliminary notes on some new species of Squilla. Johns Hopkins Univ Circle. 1891;10:93-4.

Bigelow RP. Scientific results of explorations by the U.S. Fish Commission Steamer "Albatross". XXXII. Report on the Crustacea of the order Stomatopoda collected by the steamer "Albatross" Between 1885 and 1891, and on other specimens in the United States National Museum. Proc U S Natl Mus. 1894;17:489-550.

Hansen HJ. Isopoden, cumaceen und stomatopoden der Planktonexpedition. Ergeb. Planktonexpedition Humboldt-Stiftung. 1895;2:1-105.

Hilgendorf F. Eine neue stomatopoden-gattung Pterygosquilla Sber Ges Naturforsch Freunde. 1890:172-177.

Manning RB. Notes on some Australian and New Zealand stomatopod Crustacea, with an account of the species collected by the Fisheries Investigation Ship Endeavour. Rec Aust Mus. 1966;27(4):79-137.

Manning RB. A revision of the family Squillidae (Crustacea, Stomatopoda), with the description of eight new genera. Bull Mar Sc. 1968;18(1):105-42.

Manning RB. Stomatopod Crustacea of the western Atlantic. Studies in Tropical Oceanography 8. Coral Gables: University of Miami Press; 1969a.

Manning RB. Notes on some stomatopod Crustacea from Southern Africa. Smithson Contrib Zool. 1969b;1:1-17.

Manning RB. Eastern Pacific expeditions of the New York Zoological Society. Stomatopod Crustacea. Zoologica: Sci Contrib New York Zool Soc. 1971:56:95-113.

Miers EJ. Crustacea. Proc Zool Soc London. 1881;1881:61-79.

Milne Edwards H. Histoire naturelle des crustacés, comprenant l'anatomie, la physiologie et la classification de ces animaux 2. Paris: Librairie encyclopédique de Roret; 1837. 1834-1840.

Milne-Edwards A. Crustacés. Mission Scientifique du Cap Horn, 1882-83, Zoologie, Crustacés, 6 (2 F). Paris, France: Gauthier-Villars et fils, editor. 1891. p. 1-76.

Parisi B. Elenco degli stomatopodi del Museo di Milano. Atti Soc Ital Sci Nat. 1922;61:91-114.

Schmitt WL. The Stomatopods of the west coast of America based on collections made by Allan Hancock Expeditions, 1933-38. Allan Hancock Pac Exped. 1940;5(4):129-225.

Submit your next manuscript to BioMed Central and we will help you at every step:

- We accept pre-submission inquiries

- Our selector tool helps you to find the most relevant journal

- We provide round the clock customer support

- Convenient online submission

- Thorough peer review

- Inclusion in PubMed and all major indexing services

- Maximum visibility for your research

Submit your manuscript at www.biomedcentral.com/submit 